\title{
OPTIMALISASI PENGGUNAAN KIRINYU (Chromolaena odorata) SEBAGAI SUMBER BAHAN ORGANIK DALAM PENINGKATAN PRODUKSI WORTEL (Daucus carota)
}

\author{
Murdaningsih \\ Fakultas Pertanian Universitas Flores \\ Ningsih_murda@yahoo.co.id
}

\begin{abstract}
The aim of this study was to understand the benefits of 'kirinyu' as a resource of organic matter in the growth and production of carrots and determine the optimum quantities required.

The study used a random group design method using K0 (without kirinyu), K1 (kirinyu 5 ton/ha), K2 (kirinyu10 ton/ha), K3 K3 (Kirinyu 15 ton/ha), and K4 (Kirinyu 20 ton/ha). The variables measured in this study were; plant height, total number of leaves, length of tubers, diameter of tubers and weight of fresh tubers per plant per plot and per ha.

The results of this study indicate that the use of 'kirinyu' as a source of organic matter has a definite influence in the plant height in the ages of $4 \mathrm{MST}, 8 \mathrm{MST}, 10 \mathrm{MST}$, $12 \mathrm{MST}$, and total leaves in the ages of $6 \mathrm{MST}, 8 \mathrm{MST}$. Also it influences the length of tubers, weight of tubers per plant per plot and per ha. It was determined that optimum growth of carrots; that is plant height $(32.51 \mathrm{~cm})$ total leaves $(5.78 \mathrm{~cm})$ length of tubers $(10.71 \mathrm{~cm})$ was attained with the use of $20 \mathrm{ton} /$ ha weight of fresh tubers per plant $(48.19$ grams), per plot $(7,93 \mathrm{~kg})$ and per ha $(21089,29 \mathrm{~kg})$.
\end{abstract}

Key words : Organic matter, Kirinyu, growth, production, carrots.

\section{PENDAHULUAN}

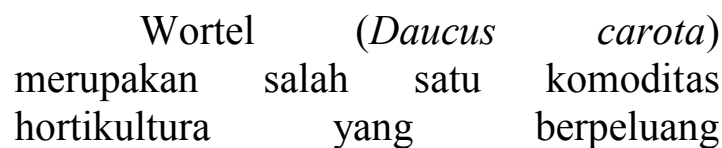
diperdagangkan dan tingginya kesadaran masyarakat akan nilai gizi (Rukmana, 2007). Wortel juga merupakan sayuran yang sudah dikenal oleh masyarakat Indonesia dan populer sebagai sumber vitamin $\mathrm{A}$, vitamin $\mathrm{B}$, vitamin $\mathrm{C}$ dan sedikit vitamin D serta zat-zat lain yang bermanfaat bagi kesehatan manusia (Widotono, 2009).

Potensi lahan yang sesuai dengan persyaratan tumbuh tanaman Wortel di Kabupaten Ende yaitu 67,5 hektar. Produksi Wortel pada tahun 2011 sebesar
937,5 ton, sedangkan produksi optimalnya 1.031,25 ton (Dinas Pertanian Kabupaten Ende, 2012). Rendahnya hasil dan produktifitas tanaman Wortel ini pada umumnya dikarenakan teknik budidaya yang kurang sesuai untuk tanaman Wortel, kebutuhan pupuk yang cukup tinggi dan kurangnya informasi dan pengetahuan petani tentang budidaya Wortel serta kurangnya kesadaran masyarakat terhadap penggunaan sumber bahan organik yang dapat meningkatkan hasil dan produktifitas tanaman (Sutanto, 2002).

Desa Pemo merupakan salah satu desa di Kecamatan Kelimutu Kabupaten Ende yang membudidayakan tanaman 
Wortel. Komoditi wortel yang mempunyai nilai komersial dapat mendukung Desa Pemo sebagai Desa wisata. Wortel sudah lama dibudidayakan masyarakat dan Desa Pemo merupakan daerah yang cocok dan sesuai dengan persyaratan tumbuh Wortel, namun teknik budidaya Wortel yang dilakukan oleh petani selama ini masih secara tradisional, sedangkan Wortel membutuhkan input yang besar.

Tanaman Wortel tidak akan memberikan hasil maksimal apabila unsur hara yang diperlukan tidak cukup tersedia. Pemupukan dapat meningkatkan hasil panen secara kuantitatif maupun kualitatif. Pemberian pupuk nitrogen merupakan salah satu unsur dalam meningkatkan produksi (Diana, 2009).

Salah satu upaya yang dapat menambah unsur hara pada tanaman Wortel untuk meningkatkan produktifitas Wortel yaitu dengan meningkatkan efisiensi penggunaan pupuk dan pemberian sumber bahan organik (Novizan, 2007). Pemberian bahan organik dalam budidaya tanaman sayuran berperan penting dalam peningkatan produktifitasnya. Bahan organik bermanfaat untuk menyuburkan dan menggemburkan tanah yang sesuai bagi pertumbuhan sayuran serta lebih menguntungkan karena lebih ramah lingkungan dan tidak mengganggu kesehatan manusia bila dibandingkan dengan pengggunaan bahan kimia (Sutanto, 2002).

Sumber bahan organik berasal dari kotoran hewan (pupuk kandang), sisa-sisa tanaman, pupuk hijau, sampah kota, limbah industri dan kompos (Atmojo, 2007). Kirinyu (Chromolaena odorata) merupakan tanaman liar yang berpotensi sebagai sumber bahan organik (pupuk hijau) yang ketersediaannya cukup melimpah dibeberapa sentra produksi tanaman sayuran (Sudiarto dan Gusmaini, 2004). Kirinyu mengandung unsur hara Nitrogen yang tinggi $(2,65 \%)$ sehingga cukup potensial untuk dimanfaatkan sebagai sumber bahan organik karena produksi biomassanya tinggi. Pada umur 6 bulan Kirinyu dapat menghasilkan biomassa sebanyak 11,2 ton/ha dan setelah berumur 3 tahun mampu menghasilkan biomassa sebanyak 27,7 to/ha, sehingga biomassa Kirinyu merupakan sumber bahan organik yang sangat potensial (Suntoro 2001 dalam Damanik, 2009).

Wardhani (2006), dalam penelitiannya juga menjelaskan bahwa produksi biomassa Chromolaena odorata adalah 18,7 ton/ha dalam bentuk segar dan 3,7 kg/ha dalam bentuk kering. Kandungan N 103,4 kg/ha; P 15,4 kg/ha; $\mathrm{K} \quad 80,9 \mathrm{~kg} / \mathrm{ha} ;$ dan $\mathrm{Ca} \quad 63,9 \mathrm{~kg} / \mathrm{ha}$. Chromolaena odorata mempunyai P total yang lebih tinggi $(0,53 \%)$ dibandingkan gulma Ficus subulata, Albizia lebeck, Macaranga sp. dan Trycospermum sp.

Hasil penelitian Anwarullah (1996) dalam Atmojo (2007) menjelaskan bahwa, penggunaan Chromolaena odorata sebagai pupuk hijau dengan dosis 10 ton/ha dapat meningkatkan produksi padi sebesar 9-15\%. Penelitian Atmojo (2007), menunjukkan penggunaan Chromolaena odorata sebagai pupuk hijau mampu meningkatkan hasil biji kacang tanah 29,79\% dengan hasil biji 2 ton/ha, dan pengaruhnya mampu menyamai pupuk kandang, serta melebihi pengaruh dari pangkasan Gliricidia sp (1,84 ton/ha), sedangkan pengaruh residu Chromolaena odorata untuk musim tanaman berikutnya justru menunjukkan pengaruh yang lebih tinggi, yaitu dengan hasil biji sebesar 2,5 ton/ha yang 
menyamai pengaruh residu pupuk kandang.

Bahan organik Kirinyu mempunyai peran yang sangat penting dalam meningkatkan produktifitas tanah dan tanaman, serta cukup tersedia dan belum dimanfaatkan secara optimal di Kabupaten Ende, khususnya di Desa Pemo Kecamatan Kelimutu yang memiliki potensi Kirinyu cukup banyak. Penelitian ini bertujuan untuk :Mengetahui pemanfaatan Kirinyu dalam meningkatkan pertumbuhan dan hasil Wortel serta mengetahui dosis optimum Kirinyu yang dapat meningkatkan pertumbuhan dan hasil Wortel.

\section{BAHAN DAN METODE}

Penelitian ini dilakukan di Desa Pemo, Kecamatan Kelimutu, Kabupaten Ende yang mempunyai ketinggian tempat 1.500 - 1.731 meter dari permukaan laut dengan suhu udara rata-rata $21^{\circ} \mathrm{C}$ pada pagi hari dan $31^{\circ} \mathrm{C}$ pada siang hari. Curah hujan rata-rata $1.000-1.500 \mathrm{~mm}$ per tahun dan kodisi tanah lempung berpasir. Bahan yang digunakan dalam penelitian ini adalah krinyu, pupuk kandang dan benih wortel.

Penelitian ini dirancang dengan menggunakan Rancangan Acak Kelompok (RAK) dengan 5 perlakuan yaitu :Ko : kontrol, K1 : 5 ton/ha Kirinyu $=2,8 \mathrm{~kg} /$ petak, $\mathrm{K} 2 \quad: 10$ ton $/$ ha Kirinyu $=5,6 \mathrm{~kg} /$ petak, $\mathrm{K} 3 \quad: 15$ ton $/ \mathrm{ha}$ Kirinyu $=8,4 \mathrm{~kg} /$ petak, $\mathrm{K} 4: 20$ ton $/$ ha Kirinyu $=11,2 \mathrm{~kg} /$ petak, Masing-masing perlakuan diulang 4 kali, sehingga terdapat 20 satuan percobaan.

Pada penelitian ini pengamatan dilakukan terhadap Tinggi tanaman $(\mathrm{cm})$, pada umur 6,8,10,12,14 minggu setelah tanam. Dan pada saat panen yang diamati adalah Panjang Umbi $(\mathrm{cm})$, Diameter umbi $(\mathrm{cm})$, Berat segar berangkasan (gram), Berat umbi segar per tanaman (gram), Berat umbi segar per satuan luas

Data yang dikumpulkan, dianalisis dengan sidik ragam. Jika dari hasil sidik ragam menunjukkan pengaruh yang nyata terhadap variabel yang dimati maka dilanjutkan dengan uji Beda Nyata Terkecil (BNT) taraf $5 \%$.

\section{HASIL DAN PEMBAHASAN}

Parameter Pertumbuhan

Hasil analisis sidik ragam menunjukkan bahwa pemberian Kirinyu berpengaruh nyata terhadap tinggi tanaman pada umur $6,8,10$ dan 12 MST (Minggu Setelah Tanam), serta tidak berpengaruh nyata pada umur 14 MST (Tabel 1).

Perlakuan pemberian Kirinyu pada setiap umur pengamatan dapat meningkatkan pertumbuhan tinggi tanaman, dimana penambahan dosis untuk setiap perlakuan (Ko, K1, K2, K3, K4) memberikan peningkatan persentase. Perlakuan dengan dosis 5 ton/ha dapat meningkatkan tinggi tanaman rata-rata sebesar 7,23\%; dari dosis 5 ton/ha ke 10 ton/ha meningkat sebesar $5,96 \%$ sehingga menjadi $13,19 \%$, dari 10 ton/ha ke 15 ton/ha meningkat sebesar $4,49 \%$ sehingga menjadi $17,68 \%$, dan dari 15 ton/ha ke 20 ton/ha meningkat sebesar $9,01 \%$ sehingga menjadi $26,69 \%$.

Meningkatnya persentase tinggi tanaman menunjukkan bahwa semakin banyak dosis bahan organik Kirinyu yang diberikan semakin meningkatkan pertumbuhan tanaman Wortel, selain itu Kirinyu sebagai sumber bahan organik mengandung unsur hara yang dapat meningkat pertumbuhan serta produksi tanaman, diantaranya jumlah kandungan unsur $\mathrm{N}, \mathrm{P}$ dan $\mathrm{K}$ juga meningkat. Pada 
pertumbuhan bagian vegetatif tanaman membutuhkan unsur $\mathrm{N}$ dalam jumlah relatif besar (Novizan, 2005). Unsur $\mathrm{N}$ merupakan unsur hara utama bagi pertumbuhan tanaman yang pada umumnya sangat diperlukan untuk pertumbuhan vegetatif tanaman (Sutedjo, 2002). Unsur $P$ dan $K$ juga mempunyai peranan yang penting untuk proses pertumbuhan, dan membantu pembentukan protein dan karbohidrat, berperan memperkuat tubuh tanaman dan lain-lain (Anonimus, 2010).

Pada umur 14 MST menunjukkan bahwa pemberian bahan organik Kirinyu berpengaruh tidak nyata terhadap tinggi tanaman Wortel. Hal ini dikarenakan pada umur 14 MST tanaman Wortel sudah memasuki fase generatif dimana bagian umbi tanaman Wortel sudah mulai terbentuk sehingga unsur hara digunakan untuk pembentukan umbi. Widotono (2009), menjelaskan bahwa pertumbuhan vegetatif Wortel berakhir pada umur 70 hari dan masuk pada fase generatif dan pada masa tersebut karakter bentuk dan ukuran umbi mulai terbentuk.
Tabel 1 Rataan Tinggi Tanaman Wortel (cm) akibat Perlakuan Kirinyu sebagai Sumber Bahan Organik pada Berbagai Umur Pengamatan.

\begin{tabular}{|c|c|c|c|c|c|}
\hline \multirow{2}{*}{$\begin{array}{l}\text { Perla } \\
\text { kuan }\end{array}$} & \multicolumn{5}{|c|}{$\begin{array}{l}\text { Rataan Tinggi Tanaman Pada Umur } \\
\text { (MST) }\end{array}$} \\
\hline & 6 & 8 & 10 & 12 & 14 \\
\hline K0 & & 11,50 & 18,72 & 25,38 & 30,9 \\
\hline K1 & $7,47_{\mathrm{a}}$ & $\stackrel{\mathrm{a}}{12,65}$ & $\stackrel{\mathrm{a}}{19,06}$ & $\begin{array}{c}\mathrm{a} \\
26,60\end{array}$ & $\begin{array}{c}1 \\
31,1\end{array}$ \\
\hline K2 & $9,61_{b}$ & $\stackrel{\mathrm{a}}{13,23}$ & $21 \stackrel{\mathrm{a}}{\mathrm{a}}$ & 28,76 & $\begin{array}{c}4 \\
32,3\end{array}$ \\
\hline K3 & $9,68_{b}$ & a & $\mathrm{ab}$ & $\mathrm{ab}$ & 3 \\
\hline K4 & $10,50_{b}$ & $\begin{array}{c}13,61 \\
a b\end{array}$ & $\begin{array}{c}22,61 \\
\text { bc }\end{array}$ & $\begin{array}{c}29,48 \\
b\end{array}$ & $\begin{array}{c}33,2 \\
3\end{array}$ \\
\hline & $10,97_{b}$ & $\begin{array}{c}15,95 \\
b\end{array}$ & $\begin{array}{l}25,55 \\
c\end{array}$ & $\begin{array}{c}32,51 \\
b\end{array}$ & $\begin{array}{c}37,1 \\
9\end{array}$ \\
\hline $\begin{array}{l}\text { BN } \\
\text { T } 5 \\
\%\end{array}$ & 1,45 & 2,59 & 3,25 & 4,40 & $\mathrm{TN}$ \\
\hline
\end{tabular}

Keterangan : Angka yang diikuti oleh huruf yang sama pada kolom yang sama menunjukkan tidak berbeda nyata pada taraf $5 \%$ uji BNT.

Parameter Produksi

Hasil analisis sidik ragam menunjukan bahwa pemberian Kirinyu berpengaruh nyata terhadap panjang umbi, berat berangkasan, berat umbi segar per tanaman, berat umbi segar per petak, berat umbi segar per Ha (Tabel 2). 
Tabel 2 Rataan Parameter Produksi Tanaman Wortel akibat Perlakuan Kirinyu sebagai Sumber Bahan Organik pada saat Panen.

\begin{tabular}{|c|c|c|c|c|c|c|}
\hline $\begin{array}{l}\text { Perla } \\
\text { kuan }\end{array}$ & $\begin{array}{c}\text { Panjang } \\
\text { Umbi } \\
(\mathrm{cm})\end{array}$ & $\begin{array}{c}\text { Dia } \\
\text { mate } \\
\mathrm{r} \\
\mathrm{Umb} \\
\mathrm{i} \\
(\mathrm{cm})\end{array}$ & $\begin{array}{c}\text { Brt } \\
\text { Brgksa } \\
n \\
\text { (gram) }\end{array}$ & $\begin{array}{c}\text { BUS/T } \\
\text { an. } \\
\text { (gram) }\end{array}$ & $\begin{array}{c}\text { BUS/ Ptk } \\
\quad(\mathrm{Kg})\end{array}$ & $\begin{array}{c}\text { BUS / Ha } \\
(\mathrm{Kg})\end{array}$ \\
\hline K0 & $8,18_{a}$ & 3,47 & $170,63_{\mathrm{a}}$ & $25,47_{\mathrm{a}}$ & $7,93_{\mathrm{a}}$ & $14160,71_{\mathrm{a}}$ \\
\hline K1 & $8,32_{\mathrm{a}}$ & 3,58 & $198,13_{\mathrm{b}}$ & $29,22_{\mathrm{ab}}$ & $9,00_{b}$ & $16071,43_{b}$ \\
\hline $\mathrm{K} 2$ & $9,24_{\mathrm{ab}}$ & 3,90 & $213,44_{b}$ & $30,63_{b}$ & $9,69_{\mathrm{b}}$ & $17303,57_{b}$ \\
\hline K3 & $10,28_{b}$ & 4,08 & $244,38_{c}$ & $39,84_{b c}$ & $10,12_{\mathrm{c}}$ & $18071,43_{\mathrm{c}}$ \\
\hline K4 & $10,71_{b}$ & 4,44 & $298,75_{d}$ & $48,19_{\mathrm{c}}$ & $11,81_{d}$ & $21089,29_{d}$ \\
\hline $\begin{array}{c}\text { BNT } \\
5 \%\end{array}$ & 1,69 & $\mathrm{TN}$ & 20,01 & 12,55 & 0,57 & 1023,38 \\
\hline
\end{tabular}

Keterangan: Angka yang diikuti oleh huruf yang sama pada kolom yang sama menunjukkan tidak berbeda nyata pada taraf $5 \%$ uji BNT.

Hasil penelitian menunjukkan rataan panjang umbi terjadi peningkatan prosentase rata-rata $1,72 \% ; 11,06 \%$ ;11,26\% ; 4,19\%. Rataan diameter umbi menunjukkan bahwa pemberian Kirinyu berpengaruh tidak nyata. Namun penggunaan dosis Kirinyu 20 ton/ha menunjukan diameter umbi yang paling besar $(4,44 \mathrm{~cm})$ jika dibandingkan dengan kontrol $(3,47 \mathrm{~cm})$. Dan ratan berat berangkasan per tanaman pada perlakuan 20 ton/ha Kirinyu memberikan hasil terbaik $(298,75 \mathrm{~g})$ dibandingkan dengan kontrol $(170,63 \mathrm{~g})$, dimana terjadi peningkatan berat berangkasan per tanaman sebesar $60,6 \%$. Adapun Rataan berat umbi segar per tanaman dengan perlakuan pemberian Kirinyu pada setiap perlakuan penambahan dosis setiap perlakuan (ko, k1, k2, k3, k4) memberikan peningkatan persentase ratarata $14,73 \% ; 4,83 \% ; 30,07 \% ; 20,96 \%$. Untuk Rataan berat umbi segar per petak $(200 \mathrm{~cm} \times 280 \mathrm{~cm})$ perlakuan 20 ton/ha
Kirinyu memberikan hasil berat umbi segar per petak terbaik $(11,81 \mathrm{~kg})$ jika dibandingkan dengan kontrol $(7,93 \mathrm{~kg})$, dimana terjadi peningkatan sebesar $42,31 \%$. Rataan berat umbi segar per ha peningkatan dosis pada setiap perlakuan meningkatkan (Ko, K1，K2，K3，K4) memberikan peningkatan persentase ratarata $13,49 \% ; 7,67 \% ;, 44 \% ; 16,70 \%$.

Meningkatnya produksi Wortel pada tiap perlakuan menunjukan bahwa unsur hara yang terdapat di dalam bahan organik Kirinyu yang diberikan pada tanaman Wortel berpengaruh terhadap pembentukan umbi Wortel. Dengan kandungan bahan organik yang tinggi dan kandungan $\mathrm{C}$ organik tinggi maka berpengaruh terhadap panjang umbi, diameter umbi dan berat umbi. Menurut Sudjijo (1994), kandungan bahan organik dan $\mathrm{C}$ organik yang tinggi akan mempengaruhi terbentuknya serat-serat yang lebih besar pada umbi, sehingga mempengaruhi kekerasan umbi dan akhirnya sangat berpengaruh pada hasil tanaman. Sarief (1989), menyatakan bahwa dengan tersedianya unsur hara dalam jumlah memadai, maka proses fisiologis di dalam tanaman akan berjalan baik, terutama unsur hara yang berperan dominan dalam pertumbuhan dan perkembang tanaman. Hasil fotosintesis yang berupa karbohidrat selain disuplai ke batang, daun dan akar juga disuplai untuk perkembangan generatif tanaman, dan tersimpan sebagai cadangan makanan (Harjadi, 1989).

Adanya pengaruh baik dari pemberian Kirinyu diduga dipengaruhi unsur $\mathrm{K}$ yang terdapat di dalam bahan organik Kirinyu yang diberikan pada tanaman Wortel berpengaruh terhadap pembentukan umbi Wortel. Berdasarkan hasil analisis kandungan bahan organik Kirinyu, terdapat $0,99 \%$ unsur K. Unsur 
$\mathrm{K}$ berfungsi sebagai perangsang pembentukan akar, selain itu unsur $\mathrm{K}$ juga berperan sebagai aktivator dari berbagai enzim esensial dalam reaksi fotosintesis dan respirasi, mengatur potensi osmotik sel, dan mengatur tekanan turgor sel (Anonimus, 2008).

Jamilah (2008) dalam

penelitiannya tentang tanaman Kirinyu menjelaskan bahwa Kirinyu ternyata mempunyai potensi untuk digunakan sebagai tanaman pupuk hijau. Biomassa Kirinyu mempunyai kandungan hara yang cukup tinggi, mengandung hara nitrogen $2,65 \% \mathrm{~N}$, mengandung hara fosfor $0,53 \%$ $\mathrm{P}$ dan mengandung hara kalium $1,9 \% \mathrm{~K}$ sehingga biomassa Kirinyu merupakan sumber bahan organik yang potensial untuk perbaikan kesuburan tanah dan meningkatkan hasil serta produksi tanaman.

Meningkatnya persentase berat umbi segar per tanaman pada tiap perlakuan menunjukkan bahwa peningkatan bahan organik memberikan pengaruh baik terhadap hasil tanaman. Sejalan dengan hasil penelitian Delgado dan Follet (2002) dalam Diah Listyarini (2010) menyatakan bahwa bahan organik yang ditambahkan ke dalam tanah dapat meningkatkan kandungan karbon di dalam tanah. Pengaturan jumlah karbon di dalam tanah meningkatkan produktifitas tanaman dan keberlanjutan umur tanaman karena dapat meningkatkan kesuburan tanah dan penggunaan hara secara efisien.

Mulyani (2002), menjelaskan bahwa bahan organik dapat menambah tersedianya bahan makanan (unsur hara) bagi tanaman yang dapat diserapnya dari dalam tanah sehingga tanaman dapat tumbuh dan berproduksi dengan baik. Atmojo (2007) menyatakan bahwa Chromolaena odorata (Kirinyu) merupakan salah satu tanaman nonlegume yang mempunyai potensi untuk digunakan sebagai bahan tanaman pupuk hijau karena biomasa Chromolaena odorata mempunyai kandungan hara yang cukup tinggi $(2.65 \% \mathrm{~N}, 0.53 \% \mathrm{P}$ dan $1.9 \% \mathrm{~K})$ sehingga biomasa Chromolaena odorata merupakan sumber bahan organik yang potensial untuk perbaikan kesuburan tanah dan meningkatkan hasil serta produksi tanaman.

Kirinyu cukup potensial untuk dimanfaatkan sebagai sumber bahan organik karena produksi biomassanya tinggi. Dari hasil analisis Kirinyu mempunyai kandungan hara $\mathrm{N} \mathrm{4,10 \% ;} \mathrm{P}$ $0,21 \%$; dan K 0,99\% . Unsur-unsur inilah yang dapat meningkatkan hasil dan produksi Wortel. Anonimus (2007), menjelaskan bahwa peranan langsung bahan organik adalah untuk menyuplai nutrien bagi tanaman. Bahan organik yang ditambahkan ke dalam tanah akan menambah unsur hara baik makro maupun mikro yang dibutuhkan oleh tumbuhan, sehingga pemupukan dengan pupuk anorganik yang biasa dilakukan oleh para petani dapat dikurangi kuantitasnya karena tumbuhan sudah mendapatkan unsur-unsur hara dari bahan organik yang ditambahkan kedalam tanah tersebut. Efisiensi nutrisi tanaman meningkat apabila permukaan tanah dilindungi dengan bahan organik (Sarwono 2007). 


\section{SIMPULAN DAN SARAN}

Simpulan

1. Pemanfaatan tanaman Kirinyu sebagai sumber bahan organik dapat meningkatkan pertumbuhan dan hasil tanaman Wortel dan berpengaruh nyata terhadap tinggi tanaman pada umur $6-12$ MST dengan peningkatan sebesar $26,69 \%$ dan jumlah daun $6-8$ MST meningkat sebesar $14,74 \%$. Untuk komponen produksi yaitu peningkatan dosis berpengaruh nyata, dan dosis 20 ton/ha menunjukkan peningkatan terhadap terhadap panjang umbi $(28,69 \%)$, berat berangkasan $(60,6 \%)$, berat umbi segar per tanaman $(70,59 \%)$, berat umbi segar per petak $(42,31 \%)$ dan berat umbi segar per /ha (42,3\%).

2. Dosis optimum Kirinyu diperoleh dengan dosis 20 ton/ha yang dapat meningkatkan pertumbuhan Wortel yaitu: tinggi tanaman $(37,19 \mathrm{~cm})$ dan jumlah daun $(6,75$ $\mathrm{cm})$ serta hasil tanaman Wortel yaitu: panjang umbi $(10,71 \mathrm{~cm})$, berat berangkasan per tanaman (298,75 g), berat umbi segar per tanaman $(48,19 \mathrm{~g})$, berat umbi segar per petak $(11,81 \mathrm{~kg})$, dan berat umbi segar per ha $(21089,29$ $\mathrm{kg})$.

1. Perlu dilakukan kajian tentang pemanfaatan Kirinyu dengan memanfaatkan teknologi lain.

\section{UCAPAN TERIMA KASIH}

Penelitian ini sangat bermanfaat bagi bagi masyarakat, khususnya sekitar kawasan Balai Taman Nasional Kelimutu (BTNK), Peneliti menyampaikan ucapan limpah terimakasih kepada Kepala BTNK atas kerjasamanya dan telah menjadi Sponsor penelitian ini, kepada Rektor Universitas Flores serta Yayasan Perguruan Tinggi Flores atas dukungan dalam pengembangan Dosen, serta seluruh rekan-rekan Dosen, Staff serta mahasiswa-mahasiswi faperta

\section{DAFTAR PUSTAKA}

Anonimus. 2007. Peranan Bahan Organik Terhadap Kesuburan Tanah dan Tanaman. http://blog.unila.ac.id/wasetawan/fil es/2009/10/peranan-bahan-organikterhadap-kesuburan-tanahtanaman.pdf. Disidir tanggal 06 Agustus.2010.

Anonimus. 2008. Pengaruh Dosis Pupuk N,P dan K Terhadap Pertumbuhan dan Produksi Tanaman wortel di Lahan Kering. http://www.gerbang.pertanian.com/ 2010/04/proses-pertumbuhantanaman.html. Disidir tanggal 01 Januari 2011.

Anonimus. 2008. Teknik Cara Membuat Tanah Tetap Subur Dan Tips Pengawetan Tanah - Ilmu Biologi. http://organisasi.org/teknik-caramembuat-tanah-tetap-subur-dantips-pengawetan-tanah-ilmubiologi. 08 september 2010 .

Anonimus.2010. Fungsi Daun. http://blog.unila.ac.id/wasetawan/fil es/2009/10/

Funsi-daun-tanaman.pdf. Disidir tanggal 06 Agustus.2010.

Atmojo Suntoro Wongso. 2007. Kandungan Unsur Hara Jaringan Kirinyu. 
HTTP://SUNTORO.STAFF.UNSA

C.ID. Disidir tanggal 04 agustus 2010.

Atmojo Suntoro Wongso. 2007. Peranan Bahan Organik Terhadap Kesuburan Tanah dan Upaya Pengelolannya.http://Suntoro.staffu ns.ac.id/files/

2009/04/pengukuhan-prof-Suntoro.pdf. Disidir tanggal 09 Agustus 2010.

Damanik Junaidi. 2009. Pengaruh Pupuk Hijau Kirinyu (Chromolaena odorata) Terhadap pertumbuhan dan Produksi Jagung (Zea mays). Skripsi, Medan.FakultasPertanianUniversita sSumatraUtara.http://repository.usu. ac.id./bitstream/123456789/7573/11 09E/228.pdf. Disidir tanggal 04 mei 2010 .

Diana Kusuma. 2009. Peranan Unsur Hara Dalam Meningkatkan Kesuburan Tanah dan Tanaman. http://organisasi.org/teknik-caramembuat-tanah-tetap-subur-dantips-pengawetan-tanah-ilmubiologi. Disidir tanggal 12 Januari 2011.

Dinas Pertanian Kabupaten Ende. 2012. Hasil dan Produksi Tanaman Wortel. Ende.

Jamilah.2008. Mencari Sumber Pupuk Organik.

Http://repository.su.ac.id/beister

am/123456789/1133/1/tanah-jamilah.pdf. Disidir tanggal 04 agustus 2010.

Mulyani. 2002. Pupuk dan Cara Pemupukan. PT Rineka Cipta Jakarta.
Novizan. 2007. Petunjuk Pemupukan Yang Efektif. Agromedia Pustaka. Jakarta

Rukmana Rahmat.2007. Bertanam Wortel. Kanisius. Yogyakarta.

Sarwono Harjdowigeno. 2007. Peranan Bahan Organik Tanah.http://isroi.Word pres.com/2009/01/29/perananbahan-organik -tanah. Disidir tanggal 06 Agustus 2010.

Sudiarto dan Gusmaini 2004. Jurnal Penelitian dan Pengembangan Pertanian Indonesia. Badan Penelitian dan Pengembangan Pertanian - Departemen Pertanian.

Sudjijo. 1994. "Pengaruh Beberapa Jenis Pupuk Organik terhadap Pertumbuhan dan Hasil Wortel" dalam Jurnal Hortikultura Balai Penelitian Hortikultura Brastagi.

Sutedjo M.M. 2002. Pupuk dan Cara Pemupukan. PT Asdi mahasatya. Jakarta

Sutanto Rachman.2002. Penerapan Pertanian Organik. Kanisius. Yogyakarta.

Wardhani. 2006. Aplikasi Mulsa Chromolaena odorata dan Cendawan Mikoriza Arbuskula Pada Tanah Latosol Untuk Pertumbuhan dan Produksi Pueraria javanica.Skripsi Fakultas Peternakan Institut Pertanian Bogor.Http://iirc.ipb.id.jspui/bitstre am//1/Wardhani.\%20Niken\%20Dya h_D2006_abstract.pdf. Disidir tanggal $0 \overline{6}$ mei 2010 . 
Murdaningsih: optimalisasi penggunaan kirinyu (Chromolaena odorata)

Wibowo Agung. 2009. Peran Pupuk Organik.

http://www.tanindo.com.abdi9/hal 3501.htm. Disidir tanggal 06 mei 2010.

Widotono Henri. 2009. Pengembangan Agribisbis Wortel. Http://hendriwd.blogspot.com/2009 /02/prospek-pengembanganagribisnis wortel.html. Disidir tanggal 26 April 2010. 